JURNAL KETAHANAN NASIONAL

Vol.23, No.2, Agustus 2017, Hal 125-144

DOI:http://dx.doi.org/ 10.22146/jkn.26257

ISSN:0853-9340(Print), ISSN:2527-9688(Online)

Online sejak 28 Desember 2015 di :http://jurnal.ugm.ac.id/JKN

VOLUME 23

No. 2, Agustus 2017

Halaman 125-144

\title{
Strategi Adaptasi Masyarakat Pesisir Dalam Penanganan Bencana Banjir Rob Dan Implikasinya Terhadap Ketahanan Wilayah (Studi Di Desa Bedono Kecamatan Sayung Kabupaten Demak Jawa Tengah)
}

\author{
Akhmad Asrofi \\ Zeni Kodam XVII/Cenderawasih \\ Email: asrofiakhmad@gmail.com \\ Su Ritohardoyo \\ Fakultas Geografi UGM \\ Email: surito@ugm.ac.id \\ Danang Sri Hadmoko \\ Fakultas Geografi Universitas Gadjah Mada \\ Email: danang@geo.ugm.ac.id
}

\begin{abstract}
The purposes of the research were (1), to determined the adaptation strategy of the peoples of Bedono village, Sayung sub-district of Demak regency in handling tidal flood disaster, and (2) to analized the implications of the tidal flood disaster for regional resilience in the Bedono village Sayung sub-district of Demak regency. The research was qualitative research with descriptive explanation. Data collection in this research used observation, in-depth interview, documentation study and literature study. The result of the research showed that the peoples of Bedono village as coastal communities did various kinds of adaptation strategies in dealing with tidal flood disaster. The adaptation strategies were done by (1) phisically adaptation strategy, (2) economically adaptation strategy, and (3) social adaptation strategy. The tidal flood disaster implicated to regional resilience of Bedono village. The tidal flood disaster implicated to geography gatra, demography, source of natural wealth, economy, social and culture. Ideology gatra, politic, and security was not being implicated by tidal flood disaster.
\end{abstract}

Keywords: Adaptation Strategy, Coastal Communities, Tidal Flood Disaster, Regional Resilience.

\begin{abstract}
ABSTRAK
Tujuan penelitian ini adalah (1) menganalisis strategi adaptasi masyarakat Desa Bedono Kecamatan Sayung Kabupaten Demak dalam penanganan bencana banjir rob, dan (2) menganalisis implikasi bencana banjir rob terhadap ketahanan wilayah di Desa Bedono Kecamatan Sayung Kabupaten Demak. Penelitian ini merupakan penelitian kualitatif dengan pemaparan secara deskriptif. Pengumpulan data menggunakan observasi, wawancara mendalam, studi dokumentasi dan studi kepustakaan. Hasil penelitian menunjukkan bahwa masyarakat Desa Bedono sebagai masyarakat pesisir melakukan berbagai macam strategi adaptasi dalam menghadapi bencana banjir rob. Strategi adaptasi yang dilakukan melalui (1) strategi adaptasi secara fisik, (2) strategi adaptasi secara ekonomi, dan (3) strategi adaptasi secara sosial. Bencana banjir rob berimplikasi pada ketahanan wilayah Desa Bedono. Bencana banjir rob berimplikasi pada gatra geografi, demografi, sumber kekayaan alam, ekonomi, sosial dan budaya. Gatra ideologi, politik dan keamanan tidak terimplikasi oleh bencana banjir rob.
\end{abstract}

Kata Kunci: Strategi Adaptasi, Masyarakat Pesisir, Bencana Banjir Rob, Ketahanan Wilayah 


\section{PENGANTAR}

Indonesia merupakan salah satu negara kepulauan terluas di dunia. Panjang pesisir di Indonesia kurang lebih $81.000 \mathrm{~km}$ atau sekitar $14 \%$ dari panjang garis pantai dunia (Sunarto, 2008). Hal ini menempatkan Indonesia menjadi negara yang memiliki pesisir terpanjang di dunia setelah pesisir di Kanada. Persoalan pesisir di Indonesia menjadi masalah yang serius akibat adanya bencana. Bencana-bencana yang terjadi di wilayah pesisir disebabkan karena adanya ancaman-ancaman yang terjadi dari daratan dan proses yang terjadi dari lautan seperti banjir, banjir tsunami, gempa bumi dan lainlain (Marfai, 2014).

Banjir air pasang merupakan suatu kejadian yang disebabkan oleh kenaikan muka air laut secara global. Adanya pasang naik dan pasang surut akan mempengaruhi kondisi genangan yang terjadi. Fenomena ini menghadirkan kejadian banjir yang disebabkan oleh kenaikan muka air laut yang disebut dengan banjir rob (Suhelmi, 2009). Area genangan rob pada saat air laut mengalami pasang tertinggi akan meningkat dan meluas ke daratan sesuai dengan elevasi muka tanah atau morfologi daratan pantai.

Potensi yang sangat tinggi di kawasan pesisir membawa perkembangan kebudayaan dan konsentrasi pembangunan, perkembangan perkotaan dan aktivitas manusia terpusat dan terkonsentrasi di daerah tersebut (Marfai, 2014). Aktivitas manusia di wilayah pesisir merupakan salah satu faktor pemicu yang akan mempengaruhi dinamika pesisir (Rijanta, dkk., 2014). Aktivitas manusia untuk menggunakan wilayah pantai menjadi tambak dan pemukiman membuat wilayah pesisir menjadi lebih rentan.
Bencana merupakan ancaman terbesar bagi kemanusiaan yang secara langsung dapat menggoyahkan dan menurunkan ketahanan wilayah. Ketahanan wilayah adalah kondisi dinamik suatu wilayah yang meliputi seluruh aspek kehidupan masyarakat yang terintegrasi, berisi keuletan dan ketangguhan yang mengandung kemampuan mengembangkan kekuatan wilayah dalam menghadapi dan mengatasi segala tantangan, ancaman, hambatan serta gangguan baik yang datang dari dalam dan dari luar, yang langsung maupun tidak langsung (Lemhannas, 2000).

Kabupaten Demak merupakan salah satu daerah yang sering terkena banjir rob yang menyebabkan perubahan penggunaan lahan. Jumlah desa di pesisir Kabupaten Demak yang terkena banjir rob adalah 17 desa yang tersebar di 3 kecamatan yakni Kecamatan Sayung, Kecamatan Bonang dan Kecamatan Karangtengah (Ritohardoyo, dkk., 2014). Kecamatan Sayung merupakan kecamatan yang paling parah terkena imbas dari bencana rob. Sejumlah 10 desa dari 17 desa yang terdampak rob di Kabupaten Demak merupakan bagian administratif dari Kecamatan Sayung. Desa yang terjadi bencana rob di Kecamatan Sayung adalah Desa Sriwulan, Bedono, Purwosari, Gemulak, Sidogemah, Tugu, Timbulsloko, Sidorejo, Surodadi dan Banjarsari.

Bencana banjir rob yang terjadi di Desa Bedono mempengaruhi kondisi fisik, ekonomi dan sosial kehidupan masyarakat yang berada di dalamnya. Terjadinya bencana banjir rob berimplikasi secara langsung kepada kondisi ketahanan wilayahnya. Kondisi ketahanan wilayah dipengaruhi oleh adanya berbagai macam bentuk tekanan yang terjadi, bisa disebabkan secara endogen 
Akhmad Asrofi, Su Ritohardoyo, Danang Sri Hadmoko -- Strategi Adaptasi Masyarakat Pesisir dalam Penanganan Bencana Banjir Rob dan Implikasinya Terhadap Ketahanan Wilayah (Studi di Desa Bedono Kecamatan Sayung Kabupaten Demak Jawa Tengah)

yaitu tekanan yang timbul dari dalam sistem maupun eksogen yaitu tekanan yang timbul dari luar sistem. Bencana banjir rob merupakan salah satu bentuk tekanan yang tercipta dari luar sistem.

Berdasarkan pengantar yang telah dipaparkan di atas, maka rumusan masalah ini adalah (1) Bagaimana strategi adaptasi masyarakat Desa Bedono Kecamatan Sayung Kabupaten Demak dalam penanganan bencana banjir rob, dan (2) Bagaimana implikasi bencana banjir rob terhadap ketahanan wilayah Desa Bedono Kecamatan Sayung Kabupaten Demak.

Penelitian ini merupakan penelitian kualitatif dengan pemaparan secara deskriptif. Pendekatan penelitian yang digunakan adalah studi pada suatu permasalahan yang terjadi di masyarakat. Pengumpulan data dalam penelitian ini menggunakan observasi, wawancara mendalam, studi dokumentasi dan studi kepustakaan. Prosedur teknik analisis data dalam penelitian ini, yaitu (1) reduksi data, (2) penyajian data, dan (3) mengambil kesimpulan.

\section{PEMBAHASAN}

\section{Profil Desa Bedono}

Desa Bedono merupakan salah satu desa yang ada di Kecamatan Sayung yang terletak di bagian utara dari pusat Kecamatan Sayung. Desa Bedono berada sekitar $3 \mathrm{~km}$ arah utara Kecamatan Sayung. Aksesbilitas dari ibukota Kecamatan Sayung ke Desa Bedono terbilang cukup baik dengan telah dibangunnya jalan cor dengan lebar $4 \mathrm{~m}$. Wilayah Desa Bedono secara geografis berada di koordinat $06^{\circ} 55^{\prime} 40^{\prime \prime}$ S - 065' $30^{\prime \prime}$ S dan $110^{\circ} 28^{\prime} 0^{\prime \prime} \mathrm{T}-110^{\circ} 30^{\prime} 30^{\prime \prime}$ T (Bappeda Kabupaten Demak, 2015). Desa Bedono merupakan desa yang paling luas di Kecamatan Sayung dengan luas wilayah mencapai 7,39 km² (10\% dari luas Kecamatan Sayung).

Penyelenggaraan sekolah formal di Desa Bedono sangat terbatas, hal ini dapat dilihat dari jumlah gedung sekolah yang berada di desa tersebut. Penyelenggaraan kegiatan belajar mengajar formal di Desa Bedono terbatas sampai hanya tingkat SD. Berdasarkan data Kecamatan Sayung dalam angka tahun 2015 di Desa Bedono terdapat sekolah Taman Kanak-kanak (TK) sebanyak 1 buah dengan jumlah murid 42 murid yang diajar oleh 2 orang guru. Sekolah Dasar (SD) sebanyak 3 buah dengan jumlah murid 339 murid dan 28 guru. Penduduk yang ingin melanjutkan pendidikan ke tingkat SMP dan SMA dapat meneruskan ke desa tetangga dengan jarak kurang lebih $5 \mathrm{~km}$.

Penduduk Desa Bedono memiliki tingkat pendidikan yang tidak terlalu tinggi. Berdasarkan data dari profil Kecamatan Sayung tahun 2015 penduduk Desa Bedono yang tidak tamat SD berjumlah 549 jiwa atau sekitar $14 \%$, sedangkan yang selesai melanjutkan pendidikan sampai dengan tingkat perguruan tinggi sebanyak 21 orang atau $1 \%$. Tingkat pendidikan yang paling banyak ditempuh adalah pendidikan SLTP dan SLTA masing masing sebanyak 852 jiwa (22\%) dan 823 jiwa (21\%). Distribusi tingkat pendidikan penduduk Desa Bedono ditunjukkan pada gambar 1 .

Mata pencaharian penduduk Desa Bedono menurut profil Kecamatan Sayung tahun 2015 didominasi oleh pekerjaan sebagai buruh tani sebanyak 812 jiwa $(23,76 \%)$ pekerjaan berikutnya secara berturut turut adalah sebagai nelayan yang mencapai 702 jiwa (20,54\%), buruh bangunan 614 jiwa $(17,97 \%)$, buruh industri 
Gambar 1

Distribusi Tingkat Pendidikan Penduduk Desa Bedono

Tahun 2014

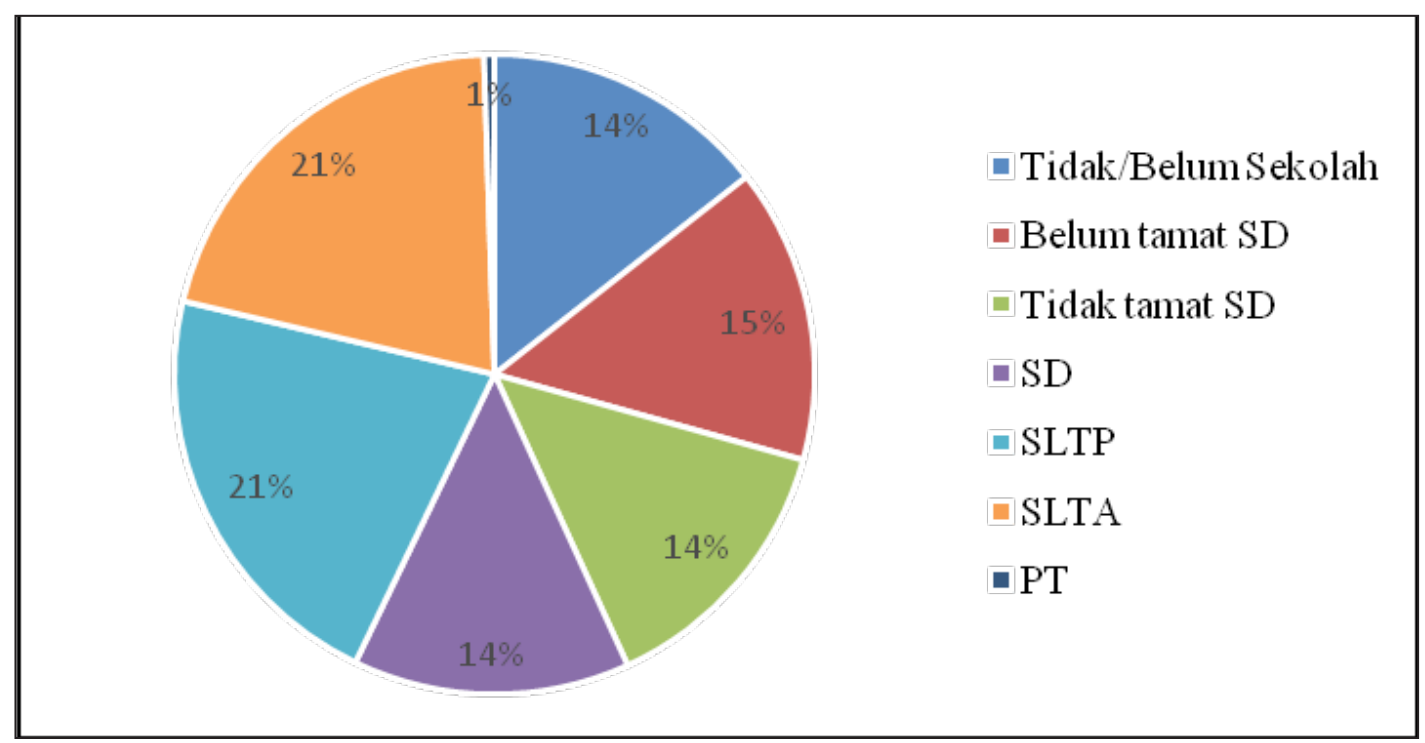

(Sumber : Bappeda Kabupaten Demak, 2015)

Gambar 2

Distribusi Mata Pencaharian Penduduk Desa Bedono

Tahun 2014

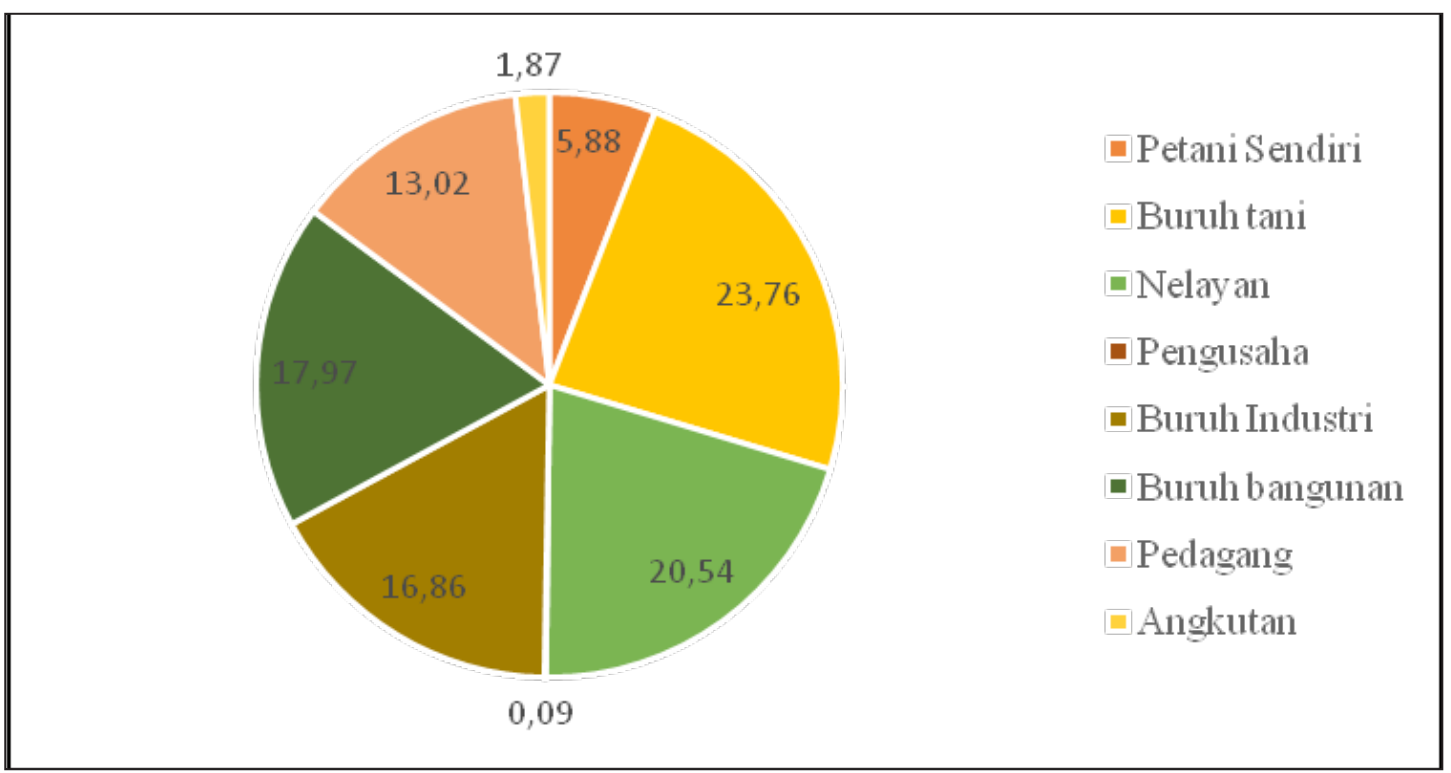

(Sumber : Bappeda Kabupaten Demak, 2015)

576 jiwa $(16,86 \%)$, pedagang 445 jiwa (13,02\%), petani pemilik lahan 201 jiwa $(5,88 \%)$, pekerja angkutan 64 jiwa $(1,87 \%)$ dan terakhir adalah sebagai pengusaha sebanyak 3 jiwa (0,09\%). Lebih lengkapnya mengenai prosentase mata pencaharian penduduk Desa Bedono dapat dilihat pada gambar 2. 
Akhmad Asrofi, Su Ritohardoyo, Danang Sri Hadmoko -- Strategi Adaptasi Masyarakat Pesisir dalam Penanganan Bencana Banjir Rob dan Implikasinya Terhadap Ketahanan Wilayah (Studi di Desa Bedono Kecamatan Sayung Kabupaten Demak Jawa Tengah)

Gambar 3

Distribusi Penggunaan Lahan Desa Bedono

Tahun 2014

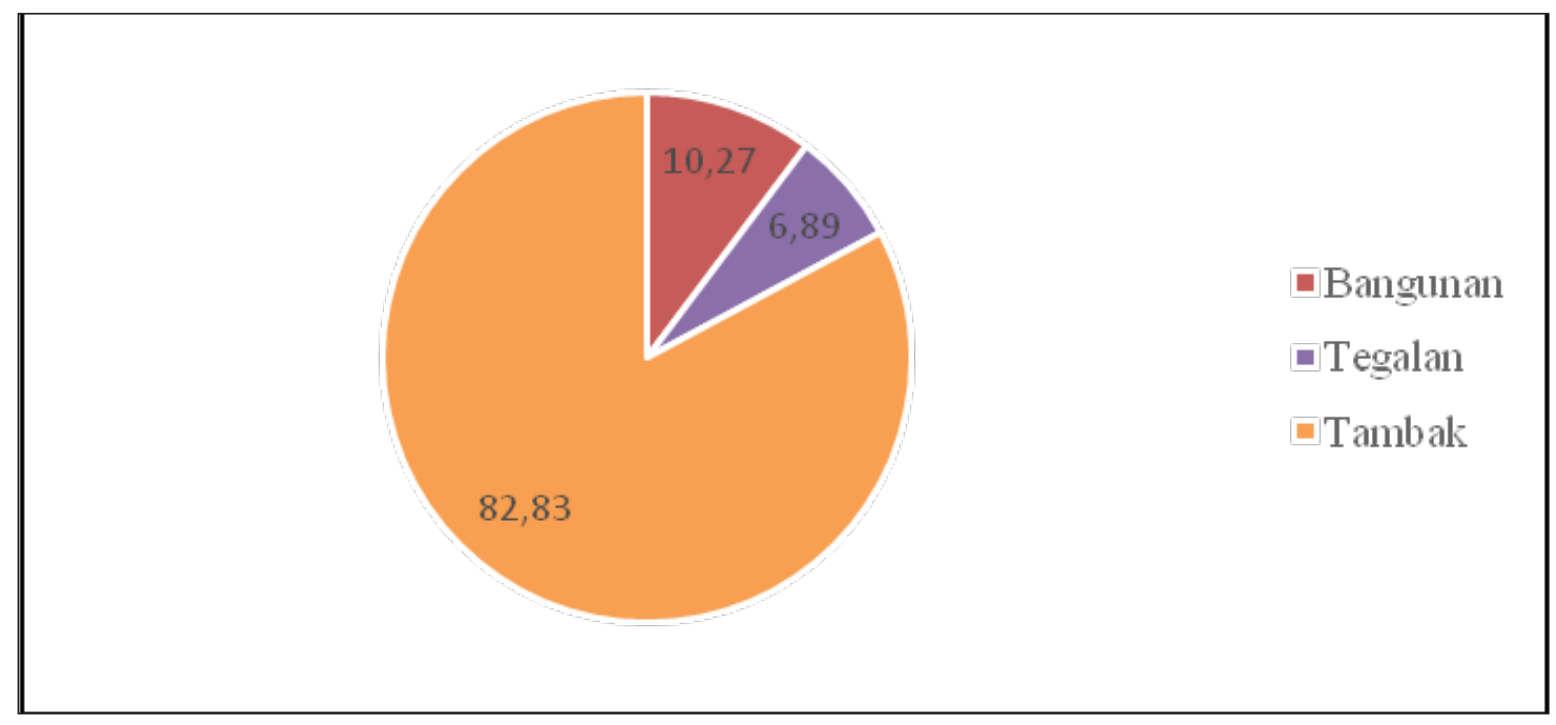

(Sumber : Bappeda Kabupaten Demak, 2015)

Dalam bidang kesehatan, fasilitas kesehatan yang terdapat di Desa Bedono hanya Puskesmas Pembantu dan Poliklinik Bersalin Desa (Polindes) dengan jumlah masing masing 1 unit. Jumlah tenaga kesehatan yang bertugas di Desa Bedono juga terbatas dimana hanya terdapat 2 petugas kesehatan saja, yaitu 1 orang bidan dan 1 orang dukun bayi. Fasilitas dan tenaga medis yang terbatas dibandingkan dengan luas wilayah dan jumlah penduduk Desa Bedono menjadi tantangan bagi pelayanan kesehatan. Apabila dalam keadaan tertentu dimana penduduk Desa Bedono mengalami gangguan kesehatan yang tidak dapat ditangani oleh Puskesmas Pembantu tersebut, dirujuk ke Puskesmas Kecamatan yang terdapat di Desa Purwosari dengan jarak tempuh sekitar $3 \mathrm{~km}$.

Kecamatan Sayung merupakan kecamatan yang paling parah terkena imbas dari bencana rob. Sejumlah 10 desa dari 17 desa yang terdampak rob di Kabupaten Demak merupakan bagian administratif dari Kecamatan Sayung. Desa yang terjadi bencana rob di Kecamatan Sayung adalah Desa Sriwulan, Bedono, Purwosari, Gemulak, Sidogemah, Tugu, Timbulsloko, Sidorejo, Surodadi dan Banjarsari.

Desa Bedono merupakan desa pesisir yang berbatasan dengan laut. Berdasarkan data Kecamatan Sayung dalam angka tahun 2015 yang membagi antara luas tanah sawah dan tanah kering, Desa Bedono terdiri dari $0 \mathrm{Ha} \mathrm{(0 \% )} \mathrm{tanah} \mathrm{sawah} \mathrm{dan} 739 \mathrm{Ha}(100 \%)$ tanah kering. Luas penggunaan tanah kering di Desa Bedono terdiri dari 74,5 Ha (10,27\%) berupa pekarangan atau bangunan, Tegalan/ kebun $50 \mathrm{Ha}(6,89 \%)$ dan tambak 600,8 Ha $(82,83 \%)$. Lebih lengkapnya mengenai prosentase penggunaan lahan di Desa Bedono dapat dilihat pada gambar 3 .

\section{Masyarakat Pesisir Desa Bedono}

Struktur masyarakat Desa Bedono merupakan masyarakat yang sederhana dan belum banyak terpengaruh secara langsung oleh pihak luar. Budaya, tatanan hidup dan kegiatan masyarakat Desa Bedono relatif 
homogen yang secara historis turun temurun hidup di daerah tersebut. Homogenitas penduduk Desa Bedono dapat dilihat dalam hal beragama dan profesi penduduknya. Dari segi keyakinan, $100 \%$ penduduk Desa Bedono merupakan pemeluk agama Islam. Dari segi profesi, masyarakat Desa Bedono sebagian besar bekerja sebagai nelayan dan petambak.

Masyarakat pesisir Desa Bedono merupakan masyarakat yang terancam secara langsung oleh bencana banjir rob. Kenaikan permukaan air laut tersebut menimbulkan kerawananan berupa tergenangnya wilayah pesisir yang mempunyai ketinggian rendah. Hal ini memberikan ancaman pada masyarakat Desa Bedono. Keterancaman masyarakat Desa Bedono dapat dilihat pada kerentanan berupa hilangnya aset yang dimiliki. Kehilangan aset seterusnya menimbulkan kesengsaraan dan menurunkan tingkat kesejahteraan masyarakat yang hidup di dalamnya.

\section{Bencana Banjir Rob Desa Bedono}

Banjir rob yang melanda di pesisir Desa Bedono mulai dirasakan oleh warga pada pertengahan tahun 1980. Rob menjadi penyebab utama menurunnya tingkat ekonomi dan sosial yang dirasakan oleh masyarakat Desa Bedono. Banjir Rob menyebabkan perubahan kondisi lingkungan dan kehidupan warga menuju suatu kondisi yang tidak menguntungkan. Hal ini menjadikan tingkat sosial ekonomi warga Desa Bedono menjadi semakin rentan. Kondisi demikian menyebabkan sebagian warga melakukan berbagai macam penyesuaian diri dan lingkungan agar tetap bertahan di tempat tinggalnya.

Frekuensi banjir genangan yang berulang dalam kurun waktu yang tidak lama menyebabkan masyarakat sudah terbiasa untuk menghadapi hal itu. Genangan akibat rob merupakan permasalahan global akibat perubahan iklim, sehingga tidak ada pilihan lain untuk menerima rob sebagai fenomena harian masyarakat Desa Bedono. Tinggi genangan yang dari waktu ke waktu semakin meningkat menyebabkan kerusakan dan gangguan yang semakin bertambah. Tinggi genangan akibat rob tidak dapat diselesaikan secara lokal apalagi pada tingkat desa, karena hal ini sudah menjadi permasalahan tingkat dunia dengan penyebab utama adalah perubahan iklim yang terjadi secara global.

Dari penelusuran penelitian yang telah ada, kejadian bencana rob di Desa Bedono dimulai pada tahun 1985. Faktor pemicunya disebabkan kegiatan reklamasi di kawasan pantai Marina dan pelabuhan Tanjung Emas Semarang Utara yang terletak di sebelah barat dari Desa Bedono (Suara Merdeka, 18 Desember 2014). Reklamasi ini memicu berubahnya arus laut yang berdampak berubahnya dinamika gelombang pasang yang menyebabkan rob dengan ketinggian 0,5-1,5 m. Selanjutnya, pada tahun 1990 terjadi alih fungsi lahan akibat booming komoditas udang windu. Hal ini mendorong masyarakat untuk meningkatkan produksi udang windu sebanyakbanyaknya salah satu cara yang digunakan adalah ekstensifikasi lahan. Perluasan lahan tambak merambah pada areal pantai yang menyebabkan perubahan hutan mangrove menjadi lahan tambak udang. Dampak negatif dari hilangnya hutan mangrove adalah terjadinya genangan pasang yang dipengaruhi oleh meningkatnya intensitas erosi pantai, rusaknya pantai akibat hantaman gelombang laut, tidak ada lagi laju yang menahan laju erosi dan tidak ada lagi habitat untuk ikan-ikan kecil yang biasanya menjadi aset para nelayan. Setyowati (2010) menyatakan bahwa setelah masyarakat menyadari mengenai pentingnya tanaman mangrove, masyarakat dan pemerintah melakukan penanaman mangrove 
Akhmad Asrofi, Su Ritohardoyo, Danang Sri Hadmoko -- Strategi Adaptasi Masyarakat Pesisir dalam Penanganan Bencana Banjir Rob dan Implikasinya Terhadap Ketahanan Wilayah (Studi di Desa Bedono Kecamatan Sayung Kabupaten Demak Jawa Tengah)

di sepanjang garis pantai Desa Bedono yang dimulai pada tahun 1997.

Hasil temuan Asiyah, dkk (2015) menunjukkan bahwa pada tahun 1999 bencana rob mengakibatkan terjadinya relokasi tempat tinggal. Sebanyak 268 kk dari Dusun Tambaksari dan Dusun Rejosari pindah ke Desa Gemulak Kecamatan Sayung. Akibat yang lain adalah hilangnya lahan tambak seluas 1.710 Ha. Rif'an (2014) menyatakan bahwa pada tahun 2000 akibat bencana abrasi dan rob terjadi perubahan garis pantai dan kerusakan pantai. Perubahan garis pantai ratarata $1,5 \mathrm{~km}$ dan terpanjang $2,46 \mathrm{~km}$. Perubahan garis pantai mengakibatkan luas lahan menjadi hilang sebesar $5,26 \mathrm{~km}^{2}$. Berbagai macam upaya pemerintah untuk menanggulangi abrasi dan rob telah banyak dilakukan. Salah satunya menurut Subagyo (2009) pada tahun 2007 dilaksanakan pembangunan tanggul penahan abrasi yang digunakan untuk melindungi kawasan daratan dari energi gelombang yang menghantam kawasan hutan mangrove secara langsung. Akan tetapi dengan kuatnya arus laut yang menerjang, membuat hasil pembangunan ini kurang efektif manfaatnya.

Hasil penelitian dari Pamungkas (2011) menunjukkan bahwa pada tahun 2001 banjir rob menggenangi 308,65 ha wilayah di Desa Bedono. Luas genangan akibat banjir rob terus bertambah, pada tahun 2006 luas genangan banjir rob menjadi sekitar 690,9 Ha. Jadi dalam kurun waktu 5 tahun telah terjadi peningkatan luas akibat bencana rob sebesar 382,25 Ha. Chafid, dkk (2012) menyatakan bahwa pemerintah mengupayakan untuk meminimalisir akibat bencana rob dan abrasi. Pada tahun 2009 pemerintah menganggarkan dana sebesar lima milyar rupiah untuk pembangunan jalan yang menghubungkan kembali Desa Sriwulan dengan Desa Bedono yang difungsikan juga sebagai penahan gelombang air laut. Selain pembangunan infrastruktur pemeritah beserta masyarakt juga melaksanakan penanaman kembali mangrove. Hal ini dapat dilihat dari bertambahnya luas ekosisem mangrove bila pada tahun 2004 luas ekosistem mangrove sebesar 22,41 Ha, meningkat menjadi 43,03 Ha pada tahun 2009. Kronologi kejadian perubahan pesisir di Desa Bedono dapat dilihat pada tabel 1.

Rob membawa dampak berupa banyak kerugian bagi masyarakat Desa Bedono. Rob yang terjadi semakin parah dengan ditandai bertambah luasnya daerah genangan dengan tinggi genangan yang semakin bertambah. Hal

Tabel 1

Kronologi Kejadian Perubahan Pesisir di Daerah Penelitian

\begin{tabular}{|c|c|}
\hline Tahun & Kronologi Kejadian \\
\hline 1985 & Kegiatan reklamasi di pesisir Kota Semarang yaitu di kawasan pantai Marina dan pelabuhan Tanjung Emas. \\
\hline 1990 & Terjadi ekstensifikasi lahan tambak yang merambah ke kawasan mangrove. \\
\hline 1997 & Dimulai upaya rehabilitasi penanaman hutan mangrove. \\
\hline 1999 & Relokasi tempat tinggal Sebanyak 268 kk dari Dusun Tambak sari dan Dusun Rejosari. \\
\hline 2000 & $\begin{array}{l}\text { Terjadi perubahan garis pantai dan kerusakan pantai. Perubahan pantai rata-rata } 1,5 \mathrm{~km} \text { dan terpanjang } 2,46 \mathrm{~km} \text {. Luas } \\
\text { lahan yang tenggelam seluas } 5,26 \mathrm{~km}^{2} \text {. }\end{array}$ \\
\hline 2001 & Banjir rob telah menggenangi 308,65 ha wilayah di Desa Bedono. \\
\hline 2006 & Banjir rob telah menggenangi sekitar 690,9 ha wilayah di Desa Bedono \\
\hline 2007 & $\begin{array}{l}\text { Pembangunan tanggul penahan abrasi yang digunakan untuk melindungi dari energi gelombang yang menghantam } \\
\text { kawasan hutan mangrove secara langsung }\end{array}$ \\
\hline 2009 & $\begin{array}{l}\text { Luas ekosistem mangrove mengalami perubahan. Luas ekosistem mangrove pada tahun } 2004 \text { sebesar } 22,41 \text { ha menjadi } \\
43,03 \text { ha pada tahun } 2009 \text {. }\end{array}$ \\
\hline
\end{tabular}

(Sumber : Suara merdeka, 2014; Subagyo, 2009; Setyowati, 2010; Asiyah, 2015; Rif'an, 2014; Pamungkas, 2011; Chafid, 2012) 
ini membawa banyak kerugian bagi masyarakat yang tinggal di dalamnya. Kerugian yang diakibatkan oleh banjir rob dapat di tinjau dari berbagai sektor kehidupan yaitu kondisi fisik dan infrastruktur, kondisi ekonomi dan kondisi sosial.

Kerusakan fasilitas publik dapat dilihat secara langsung pada bangunan-bangunan yang digunakan secara bersama-sama oleh masyarakat. Bentuk kerusakan pada bangunan ini yaitu jalan dan jembatan. Kerusakan pada badan jalan ditandai dengan rusaknya cor beton dan amblesnya tanah dasar bawah cor badan jalan. Kerusakan pada bangunan jembatan dapat dilihat pada bagian pertemuan jembatan dengan jalan penghubung (oprit). Selain kerusakan pada bagian oprit jembatan, lantai dan balok jembatan merupakan bagian lain yang mengalami kerusakan. Rusaknya dua bangunan ini sangat mengganggu masyarakat Desa Bedono untuk menjalankan segala aktivitas kehidupan.

Rob juga menjadi sebab kerusakan bangunan milik pribadi masyarakat. Berbagai bentuk macam kerusakan rumah yang disebabkan oleh rob di antaranya amblesnya pondasi, retaknya pasangan keramik lantai, rontoknya tembok, lapuknya kusen dan daun pintu. Selain menimbulkan kerugian secara fisik, banjir rob yang terjadi membawa kerugian secara ekonomi bagi masyarakat Desa Bedono. Kondisi ekonomi masyarakat Desa Bedono sangat terpengaruh oleh bencana banjir rob. Bencana rob cenderung membawa banyak kerugian ditinjau dari segi ekonomi. Nilai ekonomi menjadi berkurang bahkan hilang nilainya.

Di dusun yang mengalami tingkat banjir rob dengan frekuensi sering menyebabkan lantai rumah terus menerus tergenang air. Hal ini menyebabkan kerusakan pada struktur bawah pondasi, biaya untuk memperbaiki struktur bawah sangat tinggi. Bila masyarakat yang terdampak rob ekonominya tergolong mampu maka masyarakat tersebut melakukan perbaikan dengan meninggikan rumah, namun apabila masyarakat tersebut tidak mampu secara ekonomi, tidak ada pilihan lain selain tetap tinggal dengan lantai yang penuh dengan genangan air

Kejadian rob membawa perubahan tingkat kesejahteraan masyarakat Desa Bedono. Seperti penuturan Bapak H. Harno sebagai petani tambak bandeng. Dahulu sebelum terjadi bencana rob pendapatan setiap kali panen adalah sebesar 9-12 juta rupiah dengan rata-rata pendapatan 3 juta per bulan. Kondisi tambak sekarang tidak dapat difungsikan sama sekali. Apabila dahulu tambak dalam setahun bisa digunakan sebagai tempat budidaya sebanyak 3 kali, saat ini akibat bencana rob tambak tersebut dibiarkan begitu saja menjadi lautan. Penurunan geliat ekonomi juga dirasakan pada lokasi objek wisata di Desa Bedono. Salah satu contoh adalah penurunan pengunjung dan pendapatan di pantai Morosari yang dikelola oleh Pemda. Penurunan pengunjung lebih disebabkan kondisi lokasi wisata yang terlihat kumuh. Penurunan pengunjung dan pendapatan membuat lokasi wisata ini terancam ditutup karena rendahnya pendapatan

Rob juga telah membawa perubahan kehidupan dan strata sosial masyarakat Desa Bedono. Dahulu sebelum ada bencana rob, kehidupan masyarakat Desa Bedono termasuk dalam kategori cukup makmur. Kemakmuran Desa Bedono karena ketersediaan lahan yang menyediakan bagi warga masyarakat untuk bercocok tanam dan melakukan usaha tambak. Sebelum terjadi rob banyak warga Desa Bedono yang menjalankan ibadah 
Akhmad Asrofi, Su Ritohardoyo, Danang Sri Hadmoko -- Strategi Adaptasi Masyarakat Pesisir dalam Penanganan Bencana Banjir Rob dan Implikasinya Terhadap Ketahanan Wilayah (Studi di Desa Bedono Kecamatan Sayung Kabupaten Demak Jawa Tengah)

haji yang diperoleh dari usaha pertanian maupun usaha tambak. Rob telah mengubah lahan yang dahulu produktif menjadi lahan yang tidak produktif. Oleh sebab itu strata sosial masyarakat sosial berubah, apabila dahulu yang bergelar haji adalah orang yang berkecukupan bahkan berlebih, sekarang banyak ditemui orang yang mempunyai gelar haji namun kehidupannya sangat memprihatinkan.

Aktivitas sosial masyarakat menjadi terganggu dengan adanya bencana rob. Terganggunya aktivitas sosial ini tampak ketika ada salah satu warga yang mempunyai hajatan baik tasyakuran, khitanan, pernikahan maupun kegiatan lainnya. Padahal hari sudah ditentukan dan acara sudah disusun dengan berbagai perlengkapannya namun akan menjadi kacau apabila banjir rob dengan intensitas tinggi datang secara tiba-tiba. Hal ini tentu membuat malu tuan rumah yang mempunyai acara, terlebih apabila pada saat acara pernikahan yang melibatkan warga di luar Desa Bedono yang belum mengerti dengan keadaan Desa Bedono.

Aktivitas warga menjadi berkurang akibat rob yang menggenangi lingkungan pemukiman. Air yang masuk ke dalam rumah membuat warga mengurangi aktivitas yang biasanya dikerjakan. Kenyamanan warga dalam menjalankaan aktivitas harian juga menjadi terganggu. Namun hal ini sudah menjadi kenyataan yang harus diterima dan menjadi keseharian terutama bagi warga yang tidak mampu dalam merenovasi dan meninggikan rumahnya.

\section{Strategi Adaptasi}

Aksi adaptasi yang dilakukan masyarakat Desa Bedono dikategorikan dalam bentuk strategi secara fisik, ekonomi dan sosial.
Pertama, strategi adaptasi secara fisik. Strategi yang dilakukan oleh masyarakat Desa Bedono ini ditujukan untuk mempertahankan fungsi dari bangunan yang ada meskipun banjir rob melanda. Berbagai upaya adaptasi secara fisik yang dilakukan oleh masyarakat Bedono adalah modifikasi dan renovasi rumah, pengamanan perabotan rumah tangga, perbaikan jalan lingkungan, perbaikan saluran drainase lingkungan.

Strategi adaptasi pada aset rumah dilakukan masyarakat Desa Bedono dengan berbagai macam cara disesuaikan dengan dana yang dimiliki. Bagi warga yang memiliki uang yang banyak, rumah biasanya ditinggikan dengan cara diurug lantainya, kemudian diikuti peninggian dinding dan rangka atap. Namun bagi penduduk yang uangnya hanya cukup untuk beli tanah urugan saja, rumah yang ditinggikan hanya bagian bawah saja dengan mengurug lantai sedangkan bagian atas rumah seperti dinding dan rangka atap dibiarkan tetap tanpa ada perubahan. Bangunan seperti ini kelihatan rendah atau pendek. Agar yang punya rumah bisa masuk dan keluar pintu, maka kusen pintu dipotong. Sedangkan bagi warga yang memiliki uang pas-pasan rumah dibaut geladak dengan menggunakan kayu mahoni

Kerusakan secara fisik fasilitas warga dapat dilihat secara langsung pada jalan dan jembatan. Dari keenam padusunan yang tersisa di Desa Bedono hanya Dusun Mondoliko yang terisolir karena jalan yang ada selain sempit juga mengalami kerusakan yang cukup parah akibat rob. Akses jalan di Dusun Pandansari dan Dusun Bedono sudah baik karena sudah diperbaiki pada pertengahan tahun 2016. Satu-satunya akses jalan ke Dusun Mondoliko adalah dari Dusun Sodong Desa Sidogemah. Rob yang menerjang membuat jalan ini hanya dapat dilewati satu lajur motor saja. Masyarakat Dusun Mondoliko 
tetap berupaya agar jalan tersebut tetap berfungsi dengan melakukan kerja bakti pemasangan trucuk bambu di bagian samping jalan yang rusak sambil menunggu bantuan pembangunan dari pemerintah.

Bagi para petambak, datangnya rob membawa bencana yang ditandai dengan terendamnya tegalan sebagai pemisah dan pengatur keluar masuknya air dari dan menuju ke tambak. Tambak model konvensional yaitu tambak yang dikelilingi dengan tegalan sudah tidak ada di Desa Bedono. Tambak yang ada sekarang ini merupakan modifikasi dengan menggunakan jaring/waring sebagai pengamanan sekeliling tambak. Di Desa Bedono yang bisa dibuat tambak seperti ini adalah daerah yang berada di sebelah timur dari jalan kabupaten. Di sebelah barat dari jalan tersebut tidak bisa dibuat tambak dengan model jarring waring karena berbatasan langsung dengan laut yang dipengaruhi oleh besarnya gelombang laut.

Kedua, strategi adaptasi secara ekonomi. Rob yang menggenangi sebagian besar Desa Bedono membuat perubahan tingkat ekonomi warganya. Sebelum rob warga Desa Bedono mengandalkan pendapatan dari sektor tambak, pertanian dan hasil laut. Kondisi tambak yang sebagian besar sudah tidak dapat digunakan lagi membuat sebagian warga yang masih bertahan melakukan alih profesi. Sebagian warga yang dahulunya berprofesi sebagai petambak beralih menjadi penjaja makanan untuk para wisatawan yang mengunjungi ke makam Syeh Muzakir dan wisata alam mangrove. Profesi ini kebanyakan digeluti oleh warga Dusun Pandansari dan Tambaksari. Pendapatan yang dihasilkan digunakan untuk menutupi kebutuhan ekonomi keluarga.

Ketiga, strategi adaptasi secara sosial. Ini dapat dilihat pada bentuk proses kegiatan belajar mengajar, kesehatan, hajatan dan pemakaman. Strategi adaptasi dalam hal pendidikan ketika banjir rob datang adalah menggunakan ruang kelas yang tidak tergenang oleh banjir rob secara bersama-sama tingkatan kelas, sehingga dalam satu kelas terdapat tingkatan kelas yang berbeda. Selain itu waktu belajar mengajar juga dapat dimajukan dengan pemadatan pelajaran sehingga murid pulang lebih awal dari waktu semestinya.

Bentuk strategi adaptasi secara sosial tampak juga pada waktu kegiatan hajatan besar, dalam hal ini hajatan pernikahan atau khitanan. Masyarakat membuat beberapa alternatif tempat pelaksanaan. Apabila saat hari pelaksanaan hajatan tersebut rob datang secara tiba-tiba, maka tenda yang sudah didirikan di depan rumah yang punya hajat dipindah ke atas jalan meskipun jaraknya agak jauh dari lokasi yang punya hajat. Namun, apabila di tengah acara tersebut rob datang acara hajatan tersebut tetap dilaksanakan dengan mempercepat tempo pelaksanaan.

Strategi adaptasi pada saat pemakaman jenazah warga Desa Bedono adalah dengan membuat peti seperti perahu jadi ketika saat penggalian makam ada sumber airnya yang keluar dari liang lahat, proses pemakaman tetap dapat dilangsungkan. Selain itu bentuk strategi adaptasi adalah dengan menunggu sampai surutnya tempat pemakaman sehingga jasad warga dapat dikubur dengan baik.

Meskipun bencana rob menyebabkan penurunan kesejahteraan dan kualitas kehidupan masyarakat, sebagian masyarakat Desa Bedono tidak melakukan upaya pindah secara mandiri dan memilih untuk tetap bertahan di lokasi bencana. Kemampuan adaptasi terhadap bencana rob disebabkan beberapa hal sebagai berikut.

Pertama, tidak ada alternatif tempat tinggal. Berdasarkan penuturan sebagian 
Akhmad Asrofi, Su Ritohardoyo, Danang Sri Hadmoko -- Strategi Adaptasi Masyarakat Pesisir dalam Penanganan Bencana Banjir Rob dan Implikasinya Terhadap Ketahanan Wilayah (Studi di Desa Bedono Kecamatan Sayung Kabupaten Demak Jawa Tengah)

masyarakat yang hidup dengan genangan rob, dapat dinyatakan bahwa tidak adanya alternatif hunian memaksa mereka untuk tetap menetap di lokasi bencana dengan melakukan berbagai macam penyesuaian. Hal ini mendorong mereka untuk mengerahkan kemampuan finansial dan tenaga yang ada untuk dapat bertahan di tempat hunian yang dimiliki. Keinginan untuk pindah dari lokasi bencana sangat besar, namun karena pemerintah tidak mengakomodasi keinginan tersebut membuat warga berpikir untuk tetap menempati aset satu-satunya yang dimiliki dengan mengerahkan potensi yang dimiliki.

Kedua, pekerjaan sebagai nelayan. Warga desa memilih tetap bertahan di lokasi bencana dikarenakan faktor mata pencaharian. Mata pencaharian penduduk sebagian besar adalah sebagai nelayan yang tidak bisa hidup jauh dari pesisir dan laut. Hal ini disebabkan karena kemampuan dan keahlian yang tertanam pada sebagian besar penduduk adalah kemampuan bekerja melaut, sehingga membuat masyarakat tidak mau merasakan kesulitan apabila meninggalkan Desa Bedono dan melakukan alih profesi.

Ketiga, objek wisata di Desa Bedono. Seiring datangnya bencana rob, muncul objek wisata baru di Desa Bedono. Objek wisata ini berupa wisata bahari hutan mangrove. Tanaman mangrove yang tumbuh di Desa Bedono sebagai hasil dari upaya kerja sama pemerintah, LSM dan warga masyarakat untuk mengembangkan lahan yang tenggelam akibat banjir rob. Lambat laun seiring berjalannya waktu upaya ini membawa dampak berupa berkembangnya tanaman mangrove yang luas yang dapat menarik wisatawan berkunjung untuk menikmati hutan mangrove. Selain dari objek wisata mangrove, di Desa Bedono juga terdapat wisata religi berupa makam Syeh Muzakir. Tempat wisata religi ini banyak dikunjungi oleh warga Kabupaten Demak dan sekitarnya. Meningkatnya jumlah wisatawan mengakibatkan terbukanya profesi baru yang ditekuni oleh warga. Menjadi tukang ojek, penyewaan perahu, penyedia tempat parkir, penjual makanan merupakan jenis profesi baru yang digeluti oleh warga. Kemunculan objek wisata dan timbulnya profesi baru sebagai faktor pengikat warga untuk tetap bertahan di lokasi bencana.

\section{Kendala Pelaksanaan Strategi Adaptasi}

Pengurangan risiko bencana yang di dalamnya berupa program penanganan bencana banjir rob merupakan hal yang mendesak untuk dilaksanakan oleh masyarakat Desa Bedono bersama dengan pemerintah. Apabila program penanganan bencana banjir rob ini tidak berhasil, maka potensi kerugian harta benda maupun nyawa menjadi semakin bertambah. Keberhasilan dalam penanganan bencana banjir rob tidak lepas dari adanya partisipasi dan kerjasama antara pemerintah dengan masyarakatnya. Akan tetapi, sejalan dengan pelaksanaan penanganan bencana banjir rob di lapangan terdapat beberapa kendala yang mempengaruhi keberhasilan program tersebut.

Pertama, peningkatan intensitas dan volume bencana banjir rob. Bencana banjir rob merupakan bencana yang disebabkan oleh peristiwa astronomi dan ulah manusia. Intensitas dan besaran bencana banjir rob yang disebabkan oleh peristiwa astronomi cenderung relatif tetap. Berbeda dengan sebab tersebut, sebab banjir rob akibat ulah manusia memberi sumbangsih yang lebih besar dari sebab astronomi dan cenderung meningkat intensitas dan volumenya dari waktu ke waktu.

Banjir rob yang menggenangi Desa Bedono pada awal tahun 1990 berbeda 
besaran dan intensitasnya dengan saat ini. Meningkatnya besaran banjir rob yang terjadi membawa dampak kerugian yang lebih besar. Peningkatan besaran bencana banjir rob tersebut menyulitkan warga masyarakat yang terpengaruh secara langsung oleh rob untuk melakukan strategi adaptasi. Peningkatan volume banjir rob memerlukan upaya masyarakat yang lebih besar pula, baik dalam wujud tenaga maupun alokasi dana.

Kedua, nilai strategis Desa Bedono.

Desa Bedono terletak $20 \mathrm{~km}$ ke arah barat dari Kota Demak, dan berjarak $3 \mathrm{~km}$ dari kantor Kecamatan Sayung dan jalan Pantura Jawa. Di Desa Bedono tidak terdapat bangunan, kantor atau industri yang bernilai strategis yang memerlukan penanganan khusus. Bangunan yang terdapat di Desa Bedono hanya berupa pemukiman, tambak, sekolah dan beberapa lokasi wisata. Tidak adanya sesuatu bangunan atau instansi yang bernilai strategis menjadikan perhatian pemerintah daerah maupun pusat dalam penanganan korban bencana banjir rob tidak maksimal.

Nilai strategis suatu daerah diperlukan untuk menentukan tingkat perhatian pemerintah. Adanya sesuatu nilai yang strategis tentu menjadikan prioritas dalam penanganannya. Desa Bedono sebagai desa pesisir yang terpengaruh bencana banjir rob belum mendapatkan bantuan secara maksimal karena Desa Bedono tidak mempunyai nilai strategis.

Ketiga, keterbatasan peran pemerintah daerah. Penanganan terhadap kejadian bencana merupakan tanggung jawab bersama pemerintah bersama dengan masyarakat. Pemerintah memiliki peran dalam terwujudnya suatu bentuk manajemen bencana. Selain sebagai pihak yang menentukan kebijakan dalam merumuskan manajemen bencana, pemerintah juga berfungsi sebagai pihak fasilitator yang menyediakan sarana dan prasarana dalam penanganan terhadap suatu bencana. Menurut Dulkadir (2016) sarana prasarana memegang peranan yang sangat penting dalam pelaksanaan tugas penanggulangan bencana alam. Material atau peralatan merupakan salah satu unsur penting dalam mendukung keberhasilan dalam pelaksanaan tugas karena bencana tidak dapat ditanggulai secara efektif dan cepat tanpa menggunakan sarana material atau peralatan yang memadai.

Fungsi sebagai fasilitator dan penanganan bencana banjir rob oleh pemerintah Kabupaten Demak sudah dilakukan secara maksimal meskipun pengaruh yang dirasakan oleh masyarakat sangat kecil. Pemerintah Kabupaten Demak memandang bencana rob sebagai bencana yang kejadian dan penyebabnya terkait dengan permasalahan secara global. Oleh sebab itu, penanganan korban bencana rob tidak bisa diserahkan hanya kepada pemerintah daerah saja, perlu penanganan secara nasional dan tingkat yang lebih luas lagi.

Pemerintah Daerah Kabupaten Demak telah melakukan berbagai macam upaya agar masyarakat pesisir yang terpengaruh bencana rob dapat bertahan di lingkungannya. Penanganan yang dilakukan yaitu melakukan normalisasi sungai, penataan lingkungan wilayah hulu terutama daerah dataran tinggi Kecamatan Mranggen, melakukan koordinasi dengan Pemerintah Kabupaten Semarang mengenai penataan ruang di wilayah Ungaran yang berada di selatan Kabupaten Demak dan peninggian jalan penghubung di desa pesisir.

Keterbatasan penanganan korban bencana banjir rob disebabkan oleh keterbatasan anggaran. Peran pemerintah daerah sudah 
Akhmad Asrofi, Su Ritohardoyo, Danang Sri Hadmoko -- Strategi Adaptasi Masyarakat Pesisir dalam Penanganan Bencana Banjir Rob dan Implikasinya Terhadap Ketahanan Wilayah (Studi di Desa Bedono Kecamatan Sayung Kabupaten Demak Jawa Tengah)

maksimal meskipun tidak banyak perubahan yang dirasakan oleh masyarakat. Bencana banjir rob perlu penanganan pada tingkat pemerintahan yang lebih tinggi lagi dengan anggaran yang lebih besar. Penanganan korban bencana banjir rob dengan anggaran yang besar dapat memberikan efek yang signifikan bagi masyarakat. Hal ini karena luas sebaran, tinggi genangan dan lama genangan bencana banjir rob yang bertambah setiap waktu.

Keempat, keterbatasan kemampuan warga Desa Bedono. Adaptasi merupakan suatu penyesuaian yang digunakan manusia untuk merespon terhadap perubahan sosial dan lingkungan yang terjadi. Berbagai macam bentuk strategi adaptasi yang dilakukan oleh masyarakat tergantung dari permasalahan yang dihadapi dan sumber daya yang dimiliki. Pelaksanaan strategi adaptasi yang dilakukan oleh masyarakat Desa Bedono mengalami berbagai macam kendala.

Kendala yang dihadapi masyarakat Desa Bedono dalam melakukan strategi adaptasi adalah (1). Minimnya fasilitas infrastruktur umum. Rusaknya fasilitas umum berupa jalan dan jembatan menyebabkan pelaksanakan adaptasi secara fisik mengalami kesulitan. Hal ini sangat dirasakan oleh warga Dusun Mondoliko dalam melakukan perbaikan hunian. Transportasi bahan bangunan menjadi sulit dan membutuhkan biaya yang lebih besar. Bantuan dari pemerintah berupa perbaikan fasilitas umum berupa jalan dan jembatan merupakan faktor penting yang menjadikan motivasi tersendiri bagi masyarakat untuk tetap bertahan di lokasi bencana banjir rob. (2). Keterbatasan anggaran. Tingkat pendapatan warga Desa Bedono yang rendah menjadikan berbagai macam strategi secara fisik sulit dilakukan. Hal ini dipersulit dengan kejadian kenaikan rob yang mencapai $15-20 \mathrm{~cm}$ per tahun dan memaksa masyarakat Desa Bedono untuk melakukan perbaikan rumah dalam kurun waktu tertentu. Sumber daya yang dimiliki oleh masyarakat Desa Bedono dalam bentuk dana banyak yang diprioritaskan untuk peninggian dan perbaikan rumah. (3). Perubahan mata pencaharian tidak bisa menjamin kehidupannya lebih baik dari profesi sebelumnya. Kemunculan profesi baru seiring dengan pengembangan wisata di Desa Bedono belum membawa perubahan yang lebih baik. Penghasilan yang tidak seberapa dari profesi sebagai tukang ojek, tukang parkir dan penjual makanan hanya cukup untuk pemenuhan kebutuhan pokok saja. Kesempatan dan pilihan kerja yang terbatas dengan penghasilan harian yang kecil membuat masyarakat Desa Bedono kesulitan dalam melakukan strategi adaptasi dalam hal ekonomi. Kesulitan dalam pelaksanaan strategi adaptasi aspek ekonomi membawa dampak pada pelaksanaan startegi aspek fisik dan sosial.

\section{Hasil Penanganan Bencana Banjir Rob}

Menurut Undang-Undang RI No. 24 Tahun 2007 tentang Penanggulangan Bencana, mitigasi adalah serangkaian upaya untuk mengurangi risiko bencana, baik melalui pembangunan fisik maupun penyadaran dan peningkatan kemampuan menghadapi ancaman bencana. Salah satu faktor yang mempengaruhi besar kecilnya risiko bencana yang terjadi adalah potensi dari bencana itu sendiri. Potensi bencana yang terjadi di Desa Bedono berupa banjir rob merupakan suatu keniscayaan yang tidak dapat dihindari. Bencana seperti ini memerlukan upaya mitigasi secara struktural yang melibatkan banyak pihak, anggaran yang besar dan waktu pelaksanaan mitigasi secara terus menerus. Besarnya sumber daya yang diperlukan dalam pelaksanaan mitigasi terhadap bencana banjir rob menyebabkan proses mitigasi sulit 
dilaksanakan. Mitigasi yang sulit dilaksanakan menyebabkan pengurangan risiko bencana banjir rob tidak tertangani dengan baik.

Kerentanan merupakan faktor berikut yang menentukan besar kecilnya risiko bencana yang terjadi. Tingkat kerentanan dapat ditinjau dari kerentanan secara fisik, ekonomi dan sosial. Kerentanan fisik berkaitan dengan struktur ruang wilayah yang terdiri sarana dan prasarana wilayah yang mendukung berbagai macam aktivitas manusia. Bencana banjir rob telah membawa kerugian pada aspek fisik yang sangat besar. Kerugian ini berupa rusaknya bangunan fasilitas umum dan benda-benda pribadi milik warga.

Kapasitas atau kemampuan masyarakat dalam merespon bencana merupakan faktor berikutnya yang menentukan tingkat risiko bencana. Kapasitas merupakan konsep yang berbanding terbalik dengan kerentanan dan potensi bencana. Berdasarkan rumus risiko bencana, semakin besar kapasitas masyarakat yang terdampak bencana maka akan semakin kecil risiko bencana yang terjadi, begitu sebaliknya. Kemampuan masyarakat Desa Bedono dalam penanganan bencana rob terkendala dengan keterbatasan sumber daya yang dimiliki. Meskipun kapasitas masyarakat Desa Bedono terbatas, namun masyarakat tetap melakukan berbagai macam upaya ekologis.

Nilai risiko bencana banjir rob yang terjadi di Desa Bedono sangat besar. Hal ini karena potensi bencana dan kerentanan yang terjadi lebih besar dibandingkan dengan kemampuan masyarakat dalam menangani bencana tersebut. Besarnya risiko bencana yang terjadi menjadikan penanganan bencana tidak tertangani dengan baik. Sumber daya yang dibutuhkan dalam penanganan bencana banjir rob lebih besar dari kemampuan masyarakat maupun pemerintah. Rangkuman kerugian, bentuk strategi adaptasi dan kendala dalam penanganan bencana banjir rob Desa Bedono dapat dilihat pada tabel 2.

Tabel 2

Kerugian, Strategi Adaptasi Dan Kendala Dalam Penanganan Bencana Banjir Rob

\begin{tabular}{|c|c|c|c|}
\hline No & Kerugian & Strategi Adaptasi & Kendala \\
\hline 1 & Kerusakan Jembatan & - Perbaikan ringan & - Terbatasnya bantuan dan anggaran \\
\hline 2 & Kerusakan Jalan & $\begin{array}{l}\text { - Pengurugan dan peninggian } \\
\text { jalan }\end{array}$ & $\begin{array}{l}\text { - Bangunan tidak permanen dan perlu perbaikan berkala } \\
\text { - Dana yang terbatas }\end{array}$ \\
\hline 3 & $\begin{array}{l}\text { Kerusakan } \\
\text { pemukiman }\end{array}$ & $\begin{array}{l}\text { - Peninggian peil rumah } \\
\text { - Pengubahan struktur rumah } \\
\text { - Perbaikan rumah secara berkala }\end{array}$ & $\begin{array}{l}\text { - Pelakasanaan perbaikan secara berkala } \\
\text { - Dana yang terbatas }\end{array}$ \\
\hline 4 & $\begin{array}{l}\text { Bangunan sekolah } \\
\text { terendam }\end{array}$ & $\begin{array}{l}\text { - Penggunaan ruang kelas } \\
\text { bersama }\end{array}$ & - Bantuan dan penanganan dari pemerintah yang lambat \\
\hline 5 & Kendaraan bermotor & $\begin{array}{l}\text { - Servis secara berkala } \\
\text { - Pencucian setelah pemakaian }\end{array}$ & $\begin{array}{l}\text { - Dana yang terbatas } \\
\text { - Tergantung kondisi pemilik kendaraan }\end{array}$ \\
\hline 6 & $\begin{array}{l}\text { Kerusakan perkakas } \\
\text { rumah tangga }\end{array}$ & $\begin{array}{l}\text { - Perbaikan ringan } \\
\text { - Penggantian perkakas }\end{array}$ & - Dana yang terbatas \\
\hline 7 & $\begin{array}{l}\text { Penurunan kunjungan } \\
\text { lokasi wisata }\end{array}$ & - Perbaikan sarana dan prasarana & - Penanganan dari pemerintah yang lambat \\
\hline 8 & $\begin{array}{l}\text { Kehilangan mata } \\
\text { pencaharian }\end{array}$ & - Alih profesi & $\begin{array}{l}\text { - Terbatasnya peluang kerja } \\
\text { - Terbatasnya kemampuan dan sumber daya warga }\end{array}$ \\
\hline 9 & $\begin{array}{l}\text { Perubahan anggaran } \\
\text { belanja }\end{array}$ & $\begin{array}{l}\text { - Pengeluaran berdasarkan } \\
\text { prioritas }\end{array}$ & $\begin{array}{l}\text { - Perbaikan rumah menjadi priorotas, kebutuhan yang } \\
\text { lain dikesampingkan }\end{array}$ \\
\hline 10 & $\begin{array}{l}\text { Terganggunya proses } \\
\text { pendidikan }\end{array}$ & $\begin{array}{l}\text { - Penggunaan ruang kelas } \\
\text { bersama }\end{array}$ & - Bersifat sementara \\
\hline 11 & $\begin{array}{l}\text { Terganggunya proses } \\
\text { pemakaman }\end{array}$ & $\begin{array}{l}\text { - Penyedotan air } \\
\text { - Pembuatan peti jenazah }\end{array}$ & - Pemakaman saat rob datang dan musim hujan \\
\hline
\end{tabular}

(Sumber: Peneliti, 2016) 
Akhmad Asrofi, Su Ritohardoyo, Danang Sri Hadmoko -- Strategi Adaptasi Masyarakat Pesisir dalam Penanganan Bencana Banjir Rob dan Implikasinya Terhadap Ketahanan Wilayah (Studi di Desa Bedono Kecamatan Sayung Kabupaten Demak Jawa Tengah)

\section{Implikasinya Terhadap Ketahanan Wilayah}

Perubahan bentuk bumi mempengaruhi perubahan penggunaan lahan oleh masyarakat. Penggunaan lahan berubah, yang sebelumnya terdapat lahan yang digunakan sebagai sawah dan tegalan pada tahun 2003, berdasarkan pengamatan peneliti, saat ini sudah tidak ada lagi.
Pemanfaatan lahan yang sudah tenggelam dan tidak digunakan oleh masyarakat dimanfaatkan sebagai konservasi hutan mangrove yang saat ini sebagai objek wisata andalan bagi Desa Bedono. Perubahan penggunanan lahan di Desa bedono ditunjukkan pada gambar 4 dan 5 serta tabel 3 .

Gambar 4

Peta Sejarah Desa Bedono Tahun 2003

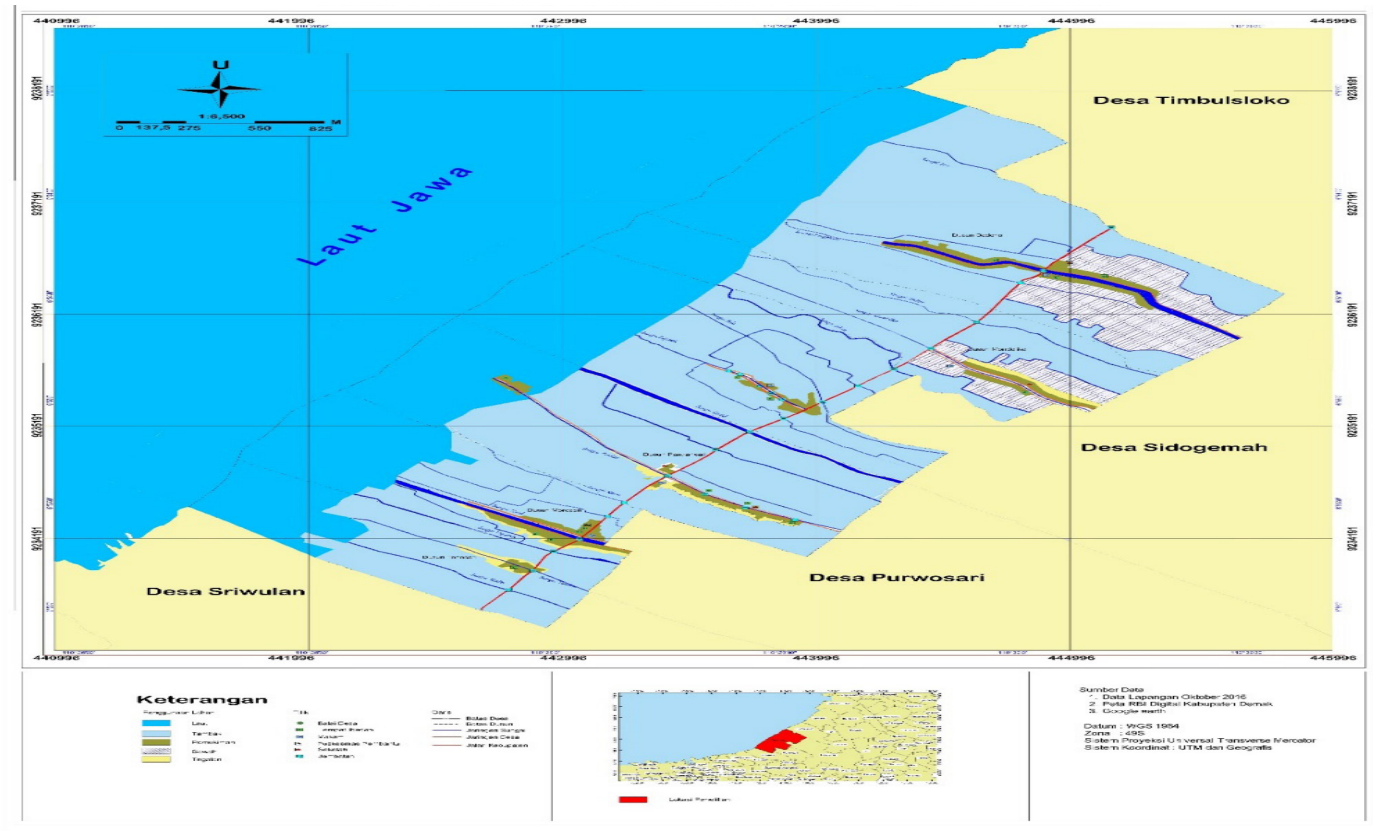

(Sumber: Asrofi, 2016)

Gambar 5

Peta Sejarah Desa Bedono Tahun 2016

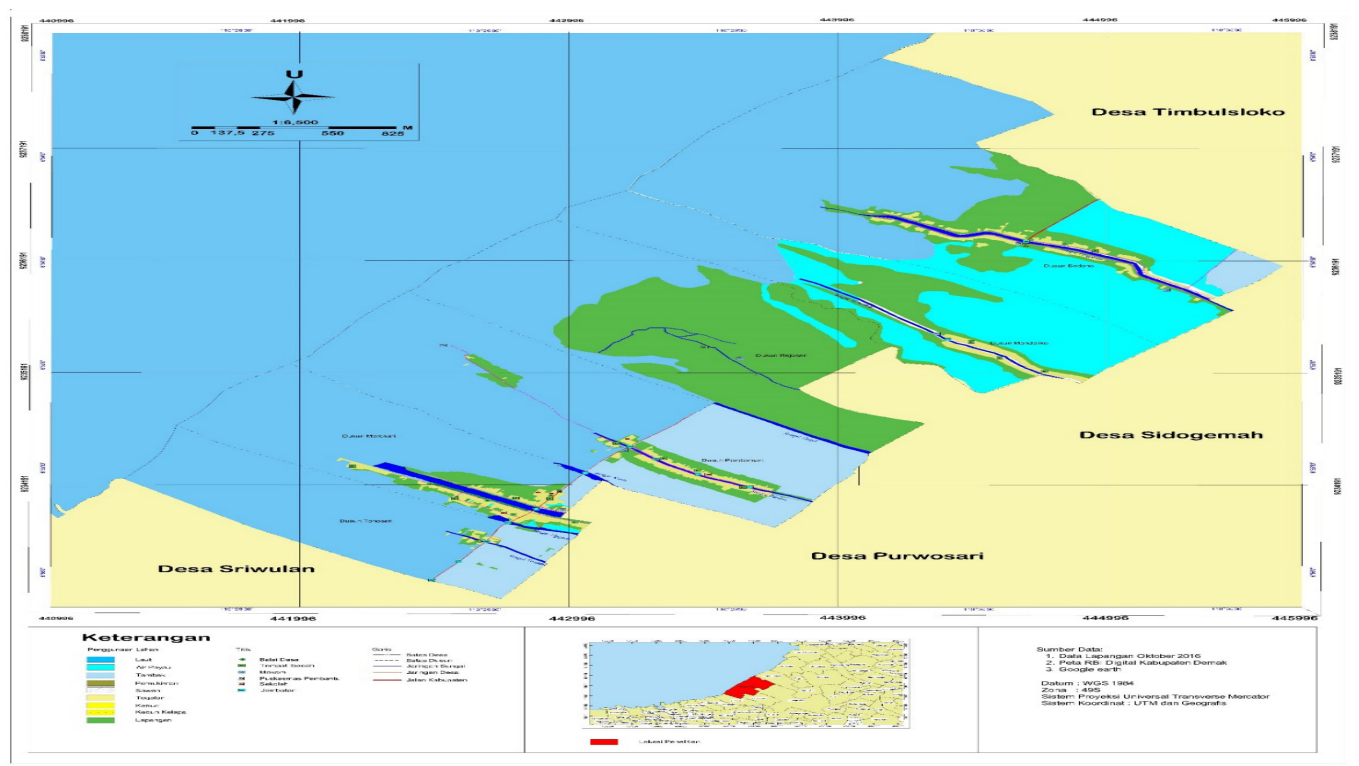

(Sumber: Asrofi, 2016) 
Tabel 3

Perubahan Penggunaan Lahan Desa Bedono Tahun 2003 dan $2014(\mathrm{Ha})$

\begin{tabular}{|c|c|c|c|c|c|c|c|c|c|c|c|c|}
\hline \multirow{2}{*}{ Dusun } & \multicolumn{2}{|c|}{ Pemukiman } & \multicolumn{2}{|c|}{ Sawah } & \multicolumn{2}{|c|}{ Tegalan } & \multicolumn{2}{|c|}{ Tambak } & \multicolumn{2}{|c|}{ Mangrove } & \multicolumn{2}{|c|}{ Lain } \\
\hline & 2003 & 2014 & 2003 & 2014 & 2003 & 2014 & 2003 & 2014 & 2003 & 2014 & 2003 & 2014 \\
\hline Tonosari & 1,1 & 0,92 & 0 & 0 & 1,74 & 0 & 63,32 & 16,21 & 0 & 0,98 & 30,3 & 78,36 \\
\hline Morosari & 8,4 & 7,35 & 0 & 0 & 2,2 & 0 & 29,1 & 3,1 & 0 & 8,96 & 62,3 & 82,59 \\
\hline Pandansari & 4,4 & 4,4 & 0 & 0 & 2,6 & 0 & 122,5 & 54,28 & 0 & 9,62 & 46,9 & 106,3 \\
\hline Rejosari & 4,1 & 0 & 0 & 0 & 0 & 0 & 74,68 & 0 & 8,31 & 110,24 & 56,85 & 43,16 \\
\hline Mondoliko & 3,6 & 3,23 & 15,3 & 0 & 0 & 0 & 78,36 & 0 & 6,69 & 25,63 & 21,86 & 89,35 \\
\hline Bedono & 28,7 & 20,1 & 43,57 & 0 & 0 & 0 & 132,08 & 0 & 4,56 & 189,76 & 62,33 & 58 \\
\hline Jumlah & 50,3 & 36 & 58,87 & 0 & 6,54 & 0 & 500,04 & 73,59 & 19,56 & 345,19 & 280,54 & 457,76 \\
\hline
\end{tabular}

(Sumber: Profil Desa Bedono, 2015)

Desa Bedono mengalami perubahan luasan daratan yang diakibatkan banjir rob. Perubahan luasan daratan menyebabkan bergesernya penggunaan lahan yang terjadi. Sebelum terjadi rob pada sekitar tahun 1990an bentukan lahan yang ada di Desa Bedono digunakan sebagai area tambak, tegalan, sawah dan pemukiman penduduk. Saat ini penggunaan lahan di Desa Bedono berubah luasan lahan yang digunakan sebagai tambak dan pemukiman menjadi berkurang karena luasan laut meningkat akibat rob. Untuk memanfaatkan lahan warga yang berubah menjadi laut, warga desa memanfaatkan lahan tersebut sebagai lahan konservasi mangrove. Rob telah menenggelamkan area yang sebagian besar lahan produktif warga Desa Bedono.

Rob menyebabkan tenggelamnya sebagian wilayah Desa Bedono. Perubahan penggunaan lahan merupakan salah satu indikator bahwa Desa Bedono memiliki permasalahan pada ketahanan wilayah.

Pertama, gatra geografi. Geografi merupakan salah satu aspek penting yang digunakan sebagai tempat tinggal bagi manusia dan untuk melangsungkan kehidupan di dalamnya. Berkurangnya ketersediaan ruang karena tenggelamnya suatu daratan sebagai tempat tinggal dan aktivitas lainnya bagi penduduk Desa Bedono adalah wujud nyata bentuk ancaman. Semakin berkurangnya ketersediaan ruang hidup bagi manusia mengindikasikan ketahanan geografi di Desa Bedono semakin rawan.

Kedua, gatra sumber daya alam.Tambak dan sawah merupakan salah satu sumber kekayaan alam yang menopang sebagian besar ekonomi warga Desa Bedono dahulu. Bencana rob yang datang telah menghilangkan sumber kekayaan alam yang sebelumnya menopang kebutuhan ekonomi sebagian besar warga Desa Bedono. Indikator hilangnya berbagai macam komoditas hasil bumi dari Desa Bedono menunjukkan bahwa ketahanan wilayah di Desa Bedono dalam gatra sumber kekayaan alam dalam kondisi yang tidak baik.

Ketiga, gatra demografi (kependudukan). Banyaknya warga Desa Bedono yang pergi meninggalkan desanya pindah ke desa lain menunjukkan bahwa ketahanan wilayah dalam aspek demografi di Desa Bedono dalam keadaan yang tidak baik. Berkurangnya ketersediaan lahan berpengaruh bagi kelangsungan hidup penduduk Desa Bedono. Jumlah penduduk Desa Bedono mengalami penurunan karena keterpaksaan untuk meninggalkan Desa Bedono dengan cara relokasi. Penduduk sudah tidak mampu bertahan di wilayah tersebut padahal penduduk merupakan subjek yang 
Akhmad Asrofi, Su Ritohardoyo, Danang Sri Hadmoko -- Strategi Adaptasi Masyarakat Pesisir dalam Penanganan Bencana Banjir Rob dan Implikasinya Terhadap Ketahanan Wilayah (Studi di Desa Bedono Kecamatan Sayung Kabupaten Demak Jawa Tengah)

menjalankan seluruh aspek yang terdapat pada gatra sosial.

Keempat, gatra ideologi. Menurut Kodiran (2006) ideologi merupakan bentuk yang digunakan untuk melakukan pembenaran terhadap tatanan sosial tertentu dan tatanan yang terjadi itu merupakan tatanan yang sudah ada dan dilestarikan, dari tatanan sosial ini membentuk sebuah keyakinan yang ada dalam setiap diri manusia untuk menjadi pedoman hidupnya sehari-hari. Indikator ketahanan wilayah pada gatra ideologi di Desa Bedono menunjukkan bahwa gatra ideologi di Desa Bedono tergolong tangguh. Hal ini terlihat bahwa warga Desa Bedono menerima Pancasila sebagai satu-satunya ideologi yang tepat dalam kehidupan berbangsa dan bernegara. Indikator lainnya adalah tidak ditemukan perkembangan ideologi lainnya baik yang berhaluan radikal kanan maupun kiri yang dapat mengancam keutuhan bernegara. Selain itu pelaksanaan kegiatan upacara sebagai wujud nyata penanaman nilainilai ideologi Pancasila terus dilaksanakan sejak dini sehingga dengan sendirinya akan mempunyai benteng pertahanan ideologi yang kuat.

Kelima, gatra politik. Gatra politik di Desa Bedono dalam keadaan tidak terpengaruh oleh bencana banjir rob. Indikator tersebut dapat dilihat pada partisipasi masyarakat dalam pelaksanaan demokrasi, penerimaan warga terhadap hasil demokrasi, indepedensi ormas keagamaan dari partai politik dan pelaksanaan musyawarah untuk mufakat.

Keenam, gatra ekonomi. Bencana rob yang terjadi di Desa Bedono berpengaruh negatif terhadap ketahanan wilayah pada gatra ekonomi. Indikator ketahanan wilayah pada gatra ekonomi yang meliputi tingkat pendapatan dan kesempatan kerja menunjukkan tingkat yang rendah, sehingga dapat disimpulkan bahwa ketahanan wilayah pada aspek ekonomi di Desa Bedono dalam kondisi kurang tangguh.

Ketujuh, gatra sosial budaya. Berdasar kualitas pendidikan warga, pelaksanaan kegiatan sosial keagamaan dan pelaksanaan kegiatan tradisi dapat dikatakan bahwa ketahanan wilayah Desa Bedono berada pada tingkat yang tidak baik. Hanya indikator tingkat konflik fisik massal antar sesama penduduk dan konflik antara penduduk dengan aparat pemerintah yang tidak terimplikasi oleh bencana banjir rob. Akibat bencana banjir rob, terjadi perubahan strata sosial dari masyarakat yang makmur dan berkecukupan menjadi masyarakat yang kekurangan. Keadaan seperti ini berdampak secara langsung terhadap tingkat pendidikan masyarakat Desa Bedono. Keadaan ekonomi yang terpuruk menyebabkan faktor pendidikan menjadi urusan yang tidak dianggap penting dan mendesak. Perubahan terjadi juga dalam hal adat istiadat dan kegiatan keagamaan yang telah lama dijalani yaitu acara anjang sana dan bersilaturahim khususnya pada hari besar Islam.

Kedelapan, gatra keamanan. Tingkat tindakan kriminalitas sebagai indikator di Desa Bedono menunjukkan dalam kondisi yang tangguh. Meskipun dalam keadaan yang serba kekurangan karena mengalami kerugian akibat bencana banjir rob, masyarakat tetap tangguh dengan masih menjaga persatuan, kesatuan dan keutuhan walaupun dalam tingkat desa. Wujud terciptanya ketahanan dalam aspek ini tercermin dalam terciptanya stabilitas di Desa Bedono. Tingkat gangguan keamanan dan kriminalitas yang terjadi di Desa Bedono dikategorikan rendah, kriminalitas merupakan tolak ukur untuk menetapkan bahwa daerah tersebut aman atau tidak. 
Tabel 4

Tingkat Pengaruh Bencana Banjir Rob Terhadap Indikator Ketahanan Wilayah

\begin{tabular}{|c|c|c|}
\hline Gatra & Indikator & $\begin{array}{l}\text { Implikasi Bencana Banjir Rob } \\
\text { Terhadap Ketahanan Wilayah }\end{array}$ \\
\hline Geografi & - Penggunaan lahan & Ada \\
\hline $\begin{array}{l}\text { Sumber } \\
\text { Kekayaan Alam }\end{array}$ & - Komoditi hasil bumi & Ada \\
\hline Demografi & - Mobilitas & Ada \\
\hline Ideologi & $\begin{array}{l}\text { - Penerimaan Pancasila sebagai ideologi berbangsa dan bernegara } \\
\text { - Perkembangan gerakan radikal kanan dan radikal kiri } \\
\text { - Pelaksanaan upacara bendera di sekolah }\end{array}$ & Tidak Ada \\
\hline Politik & $\begin{array}{l}\text { - Partisipasi masyarakat dalam pelaksanaan demokrasi } \\
\text { - Penerimaan warga terhadap hasil demokrasi } \\
\text { - Indepedensi ormas keagamaan dari partai politik } \\
\text { - Pelaksanaan musyawarah untuk mufakat }\end{array}$ & Tidak Ada \\
\hline Ekonomi & $\begin{array}{l}\text { - Tingkat pendapatan } \\
\text { - Kesempatan kerja }\end{array}$ & Ada \\
\hline Sosial Budaya & $\begin{array}{l}\text { - Tingkat pendidikan warga } \\
\text { - Konflik fisik masal antara sesama penduduk dan konflik antara aparat } \\
\text { pemerintah dengan masyarakat } \\
\text { - Pelaksanaan kegiatan sosial keagamaan } \\
\text { - Pelaksanaan tradisi budaya }\end{array}$ & Ada \\
\hline Keamanan & $\begin{array}{l}\text { - Tingkat tindakan kriminal } \\
\text { - Kepedulian masyarakat terhadap keamanan }\end{array}$ & Tidak Ada \\
\hline
\end{tabular}

(Sumber: Peneliti, 2016)

Bencana banjir rob yang terjadi di Desa Bedono berimplikasi terhadap berbagai gatra pada ketahanan wilayah. Bencana banjir rob berimplikasi terhadap 5 gatra pada ketahanan wilayah yaitu gatra geografi, sumber daya alam, demografi, ekonomi dan sosial budaya. Gatra ideologi, politik dan keamanan merupakan gatra yang tidak ada implikasi secara langsung akibat bencana banjir rob. Secara lengkap disajikan pada tabel 4.

\section{SIMPULAN}

Berdasar uraian tersebut di atas dapat ditarik simpulan sebagai berikut.

Pertama, sikap masyarakat Desa Bedono dalam menghadapi bencana rob dapat dikategorikan menjadi dua kelompok, yaitu masyarakat yang tidak dapat beradaptasi dengan bencana rob memilih pindah ke daerah lain, dan masyarakat yang melakukan berbagai macam bentuk strategi adaptasi tetap memilih tinggal di Desa Bedono tersebut.
Kedua, strategi adaptasi yang dilakukan masyarakat desa dikategorikan dalam bentuk 3 adaptasi, yaitu (1). Strategi secara fisik. Ini dilakukan masyarakat Desa Bedono dengan cara meninggikan bangunan rumah yang ditinggali, mengubah bentuk rumah menjadi bentuk panggung, membuat pengaman bambu di sepanjang jalan dan menempatkan dokumen-dukumen di tempat yang tinggi. (2). Strategi secara ekonomi. Ini dilakukan oleh warga Desa Bedono dengan cara mengubah mata pencaharian yang sebelumnya berprofesi sebagai petambak alih profesi sebagai penjual makanan, pengojek, tukang parkir dan berbagai macam pekerjaan kasar lainnya. (3). Strategi adaptasi secara sosial. Ini dapat dilihat pada kegiatan hajatan, kegiatan keagamaan dan proses pemakaman warga Desa Bedono.

Ketiga, bencana banjir rob berimplikasi terhadap ketahanan wilayah Desa Bedono. Implikasi yang diakibatkan oleh bencana banjir rob terhadap 8 gatra pada ketahanan wilayah di Desa Bedono dikelompokkan 
Akhmad Asrofi, Su Ritohardoyo, Danang Sri Hadmoko -- Strategi Adaptasi Masyarakat Pesisir dalam Penanganan Bencana Banjir Rob dan Implikasinya Terhadap Ketahanan Wilayah (Studi di Desa Bedono Kecamatan Sayung Kabupaten Demak Jawa Tengah)

dalam dua kategori, yaitu (1). Bencana banjir rob mempunyai implikasi terhadap gatra geografi, sumber kekayaan alam, demografi, ekonomi dan sosial budaya. (2). Bencana banjir rob tidak berimplikasi terhadap gatra ideologi, politik dan keamanan.

\section{DAFTAR PUSTAKA}

Asiyah, S., Rindarjono, M.G., Muryani, C., 2015, "Analisis Perubahan Pemukiman dan Karakteristik Pemukiman Kumuh Akibat Abrasi dan Inundasi di Pesisir Kecamatan Sayung Kabupaten Demak Tahun 20032013", Jurnal Geoeco, Vol. 1 No. 1, hal 25-34

Badan Perencanaan Pembangunan Daerah, 2015, Profil Kecamatan Sayung Tahun 2015, Demak

Chafid, M.A, Pribadi, R., Anugroho, A., 2012, "Kajian Perubahan Luas Lahan Mangrove di Desa Bedono Kecamatan Sayung Kabupaten Demak Menggunakan Citra Satelit Ikonos Tahun 2004 dan 2009", Journal of Marine Reseacrch Vol. 1 No.2, 2012, hal 32-40

Dulkadir, 2016, “Optimalisasi Peran Kodim Dalam Penanggulangan Bencana Banjir dan Implikasinya Terhadap Ketahanan Wilayah", Jurnal Ketahanan Nasional, Volume 22 No. 1, April 2016, hal. 94-112, ISSN. 2527-9688

Kodiran, 2006, "Perubahan Sosial dan Ideologi: Sebuah Telaah Perspektif Perubahan Sosial dan Ideologi Nasional", Jurnal Ketahanan Nasional, No. XI (2), Agustus 2006, hal. 69-74, ISSN. 0853-9340

Lemhannas, 2000, Ketahanan Nasional, Jakarta, Balai Pustaka.

Marfai, M.A., 2014, Banjir Pesisir Kajian Dinamika Pesisir Semarang, Yogyakarta, Gadjah Mada University Press,
Pamungkas, C., 2011, "Tanggapan dan Antisipasi Masyarakat Menghadapi Rob di Kecamatan Sayung Kabupaten Demak", Skripsi, Universitas Negeri Semarang, Semarang,

Rif’an, A.A., 2014, “Pemilihan Lokasi Pengembangan Pemukiman sebagai Upaya Adaptasi terhadap Banjir Pasang dan Perubahan Garis Pantai", Tesis, Universitas Gadjah Mada, Yogyakarta

Rijanta, R., Hizbaron, D., Baiquni, M., 2014, Modal Sosial dalam Manajemen Bencana, Yogyakarta, Gadjah Mada University Press.

Ritohardoyo, S., Sudrajat, Kurniawan, Andri., 2014, Aspek Sosial Banjir Genangan (Rob) Di Kawasan Pesisir, Yogyakarta, Gadjah Mada University Press.

Setyowati, E., 2010, “Partisipasi Masyarakat dalam Pengelolaan Hutan Mangrove di Desa Suradadi Kecamatan Sayung Kabupaten Demak", Tesis, Sekolah Pascasarjana Institut Pertanian Bogor, Bogor

Subagyo, Hardati, P., Handoyo, E., Tjaturahono, 2009, "Model Pelestarian Lingkungan Berbasis Masyarakat sebagai Upaya Menghadapi Berbagai Iklim", Makalah, Universitas Negeri Semarang, Semarang

Suhelmi, I.R., 2009, "Pemanfaatan Multimedia dalam Visualisasi Model Rob Berbasis Sistem Informasi Geografi Di Semarang”, Jurnal Kebencanaan Indonesia Vol. 2 No. 2 November 2009, hal 25-31

Sunarto, 2008, "Hakikat Bencana Kepesisiran dalam Perspektif Geomorfologi dan Upaya Pengurangan Resikonya", Jurnal Kebencanaan Indonesia Vol.1 No.4 Mei 2008, hal 11-15 


\section{Peraturan Perundangan}

Undang-undang Republik Indonesia Nomor 24 Tahun 2007 Tentang Penanggulangan Bencana.

Undang-undang Republik Indonesia Nomor 27 Tahun 2007 Tentang Pengelolaan Wilayah Pesisir dan Pulau-pulau Kecil.

\section{Internet \\ http://epaper.suaramerdeka.com/ read/2014/12/18/27SM18L14SMT. pdf, diakses 25 September 2016}

\section{Wawancara}

1. Bapak H. Harno 